\title{
50 YEARS OF THE BOOK KNOWLEDGE AND CONTROL: NEW DIRECTION FOR SOCIOLOGY OF EDUCATION, INTERVIEW WITH MICHAEL YOUNG
}

\author{
50 ANOS DO LIVRO KNOWLEDGE AND CONTROL: NEW DIRECTION \\ FOR SOCIOLOGY OF EDUCATION, ENTREVISTA COM MICHAEL YOUNG \\ 50 AÑOS DEL LIBRO KNOWLEDGE AND CONTROL: NEW DIRECTION \\ FOR SOCIOLOGY OF EDUCATION, ENTREVISTA CON MICHAEL YOUNG
}

\author{
Marcelo Pinheiro Cigales ${ }^{1}$ \\ Amurabi Pereira de Oliveira ${ }^{2}$ \\ Diego Greinert de Oliveira ${ }^{3}$
}

\section{Foreword}

I n 1971, Professor Michael Young organized a book that would mark a generation of researchers in Sociology of Education, inaugurating what has become conventionally known as the New Sociology of Education (NSE). In Knowledge and Control: New directions for Sociology of Education (not translated into Portuguese), Young, alongside with other authors, such as Pierre Bourdieu, Basil Bernstein, Geoffrey Esland, and Neil Keddie, proposes a discussion beyond questions centered solely on a technical curriculum, aiming almost exclusively at reflecting about the best methods and techniques to guarantee an efficiency in the curricular and teaching organization. Thus, the NSE introduces a new way of analyzing the curriculum at its origins, driving the sociological reflection on the choices, the political games, and the agents of the educational field that defined what knowledge should be taught, and how.

Moreira and Silva (2002) point out the originality of the NSE, and how it inaugurates an original sociological reflection on the curriculum. Its diffusion in the English-speaking world occurred relatively quickly, subsequently impacting other sociological traditions in Education.

It is true that, over the decades, the author himself had reformulated some questions in relation to this perspective, bringing the discussion to what he called powerful knowledge, a type of knowledge that allows students to understand the world in which they live according to their broader relationships. Thus, the question that educational systems and school institutions should have in mind is whether the curriculum is a means of achieving this powerful knowledge, a knowledge that is made available through school education and which could provide children from disadvantaged homes with intellectual development beyond their local and private circumstances (YOUNG, 2007).

In Brazil, Young's work began to gain greater notoriety from the second half of the 1980's, when his first works in the country were translated, such as the articles 'On the Subject of a Critical Sociology of

1.Universidade de Brasília - Brasília (DF), Brazil. E-mail: marcelo.cigales@unb.br

2.Universidade Federal de Santa Catarina - Florianópolis (SC), Brazil. E-mail: amurabi1986@gmail.com

3.Universidade Federal de Santa Catarina - Florianópolis (SC), Brazil. E-mail: diego_pnd@hotmail.com

Editor de Seção: Ivany Rodrigues Pino 
Education' and 'Curriculum and Democracy: Lessons from a Critique of the "New Sociology of Education"' (1989). From the 1990s, syntheses produced by some of his Brazilian interpreters also began to circulate (SILVA, 1992), as well as translations made by foreign authors, such as Jean-Claude Forquin in School and Culture: The Social and Epistemological Bases of School Knowledge (1993). This process occurred concurrently with the autonomy of the field of Curriculum Studies in Brazil, with the appearance of programs, lines of research, and specialized journals in that period.

Thinking about the curriculum from the perspective of the Sociology of Education and New Sociology of Education, introduced by Michael Young's work, becomes even more relevant when we are in the process of curricular transformation in the municipal, state, and federal spheres, articulated by the National Common Curricular Base (BNCC) for High School, approved in 2018, and by the High School Reform (2017), that drives federative units to reflect upon their curricula, senses, and identities. This discussion brings us to aspects of Young's theory that he himself began to review in a more recent period, because, despite recognizing that schools in capitalist societies reproduce social classes and other inequalities, he recognizes that ' $[. .$.$] the role of schools and the subject-based$ curriculum is more complex than sustaining inequalities' (YOUNG, 2011, p. 617).

That being said, it is also worth mentioning that this interview goes through a series of points that start from Young's professional and academic training, the influence and partnership with Basil Bernstein, the context in which the work Knowledge and Control: New directions for Sociology of Education emerged, as well as his theoretical shift, 'from a combination of phenomenology and marxism' to an approach that is 'critical to structuralism,' understood as 'social realism.' Finally, Young introduces us to the disputes in curricular formulations in England, including the attacks on Social Sciences and the challenges of a research agenda related to the Sociology of Education and the curricular issue.

Thus, the notes contained in this interview with Michael Young, Emeritus Professor of the Institute of Education at the University College London, will help readers and researchers of the curriculum to a broader and deeper look at the author's propositions and theoretical perspectives, and the work in question, that, in 2021, completes fifty years of its first edition.

We are indebted to Professor Michael Young and his kindness in answering our questions. Good reading!

\section{Interview}

\section{Professor Young, could you tell us about your educational background and professional experience by explaining how you entered the field of Sociology of Education?}

Michael Young: I studied Natural Sciences at the University of Cambridge and, after a year working for Shell in plastics sales, I became a secondary school science teacher. In the evening, I studied for a second degree in Sociology and graduated five years later, with a BSc from the University of London. I took a year (1966-1967) off teaching to study full-time for a MA in Sociology at the University of Essex. I was fortunate in having Basil Bernstein as my tutor and this led to me to apply for and be appointed as Lecturer in Sociology of Education at the Institute of Education of University of London, where Bernstein was Professor. I continued to focus on the Sociology of Curriculum that I began in my MA dissertation. This led to various un-published conference presentations and my first book Knowledge and Control. 


\section{At that time there was no establishment of a properly autonomous field of what would come to be known as 'Curriculum Sociology.' How did you specifically come to this topic?}

Michael Young: Basil Bernstein was a big influence on me in choosing my dissertation topic. Up to then, sociologists were few in number and, in England, their work grew out of demographic studies, which demonstrated the powerful role of social class in determining educational opportunities, and life chances. By the time I became a university lecturer, Bernstein was looking for ways of moving Sociology of Education beyond its 'distributional' focus. His early 1970's papers began to problematize the 'what' of education and this led to a focus on curriculum, which he developed in his well know paper in my book: 'The Classification and Framing of Educational Knowledge.'

Could you tell us how the idea of the book Knowledge and Control (1971) came about, and, in your assessment, what is the timeless of the questions raised at that time almost fifty years later?

Michael Young: In practical terms, it arose from the British Sociological Association (BSA) Annual Conference, in 1970. Its theme was Education, and Bernstein and I were involved in its planning, and both of us presented papers. We also arranged for Pierre Bourdieu, little known in the UK at the time, to be invited. The idea for the book was Bernstein's, in a meeting after the conference that he and I had with Bourdieu. We all had a feeling that it was an opportunity to bring together some of the ideas that were discussed at the conference for a broadening of the field of Sociology of Education. It was Bernstein who suggested that I edited a book, and found a publisher, and the result, a year later, was Knowledge and Control: New Directions in Sociology of Education.

Theoretically, it was a highly eclectic collection. I was in the very early stage of my academic career and what held it together, at least for me, was the relationship between power and knowledge, and how this was expressed in schooling and the curriculum. It was this relationship that has proven to be 'timeless', and has not only shaped the Sociology of Education ever since, but has been a theme underlying changes in curriculum policy in many countries. I think the most important legacy it left was that the distribution of educational opportunities and its consequences for equality and social justice can never be understood by Education as just a quantifiable 'good, like a bigger wage; it always involves ethical, political, and epistemological judgments.

Some well-known authors in the field of Sociology of Education took part in this collection, such as Bourdieu and Bernstein. How did these colleagues participate? Is it possible to point out how your work differs from the approach developed by these other two sociologists?

Michael Young: The answer to the first question is simple. Bernstein, already well-known for his sociolinguistic studies, agreed that his address to the BSA Conference, 'The Classification and Framing of Educational Knowledge, could be included, and I wrote to Bourdieu for permission to include his only papers that, at the time, had been translated into English. As to how my work since has differed from theirs, I have only the space to be brief about a question that I am currently beginning a whole book about. The fundamental cleavage between me, Bourdieu, and Bernstein was originally that they were both structuralists and, with my combination of phenomenology and marxism, I adopted an anti-structuralist, or social constructivist, position. How recently-especially in my third book, Bringing Knowledge Back in-I have modified my position and now support a critical form of structuralism that we refer to as social realism. I respect Bourdieu's 
work, but have never been happy with his key concept of 'field.' It cannot, in my view, deal with the socio-epistemic issues around knowledge that a sociologist faces in addressing the curriculum as a social production. Bernstein and I were never reconciled during his lifetime; however, my re-discovery of the importance of Durkheim has given me a new respect for his work which I think has played major, if not always recognized, role in the Sociology of Education and still does.

To what extent does your notion of 'powerful knowledge' approach or distance from the 'rational pedagogy' proposed by Bourdieu and Passeron in The Inheritors?

Michael Young: I have never found the contradiction in Bourdieu's work between disabusing one's readers of the possibility of education as a source of radical social change and using one's own prestige as a Professor to do just that, helpful or convincing. I find Bernstein's concept of 'the pedagogic device' much more useful.

Throughout your research trajectory, you have built an argument that, in Knowledge and Control, understood the curriculum as a space for struggle and social reproduction, for a perspective that recognizes the relevance of a 'powerful knowledge' that cannot be of service only of the 'powerful.' So, there is a comprehensive turn in this direction. Could we say that you have moved from an analytic-descriptive perspective to an analytical-propositional perspective?

Michael Young: This is not quite correct. In Knowledge and Control, I did see the curriculum as best analyzed in terms of what more recently I have described as 'knowledge of the powerful.' Thus, my position was of total criticism of the curriculum as always expressing the interests of those wanting to maintain their power. My revised position adopts a social realist stance, which recognizes a material, physical, and social reality, beyond anything we 'construct.' In other words, knowledge is 'socially constructed,' but, as Marx put it, 'not in circumstances of our own choosing.' It follows that, in establishing formal education, there is no alternative to recognizing the fact that there are 'communities of researchers' who seek and, in the process, achieve the nearest to the truth that we have.

In this process, the possibility of disrupting, as well as reproducing the social order is always possible. Thus, the source of emancipation, that is at the heart of the work of someone like Paulo Freire, is in the very process of creating a curriculum and, in the term I have used recently, a powerful knowledge. I think this is a somewhat different approach to your move from analytical-descriptive to analytical-propositional.

Professor, there is a movement of return to curricula, appreciation of curriculum and school subjects. Is it a form of criticism of a student-centered Pedagogy? Is it possible to advocate a curriculum that focuses on school subjects, but also dialogues with the concrete experiences that students bring to school? If so, how?

Michael Young: What has been known as 'the return to knowledge' is a direct criticism of student-centred learning and Pedagogy, and they are not, in my view, reconcilable. However, the 'return to knowledge' proposes Pedagogy as a dialogue between discipline-based knowledge and the student's experience, based on their everyday knowledge. 
Teachers are faced with what has been called the 'rupture' of student consciousness, that, engaging with school knowledge, creates with the knowledge that students bring to school. The key pedagogic and curricular alternative is the notion of developing a 'relation to knowledge' by the student, not its memorization. This is a concept that is being developed by Bernard Charlot, in Brazil, in his research at the Federal University of Sergipe. Work on this is at an early stage of development, which has hardly begun in the English tradition of Sociology of Education. It is very much at the centre of my current work with teacher educators at the UCL Institute of Education in London.

We could say that it is a relatively widespread phenomenon that the attack on the Social Sciences in school curricula has been taking place in different countries in different ways. In your opinion, what 'powerful knowledge' can the Social Sciences, as a school subject, offer to our generations in both the Northern and Southern global countries?

Michael Young: The issue of Social Sciences in the school curriculum is outside my field of expertise, and, as far as I know, has been the subject of very little research. Hence, what I write is more personal opinion and less a result of any systematic enquiry. I hope my remarks will be treated with more than the usual caution.

Sociology has been extensively offered in secondary school curricula in England, but it is now 'in retreat.' This is partly a consequence of political pressures from a decade of conservative governments, that have opposed it as not complying with their criteria of academic knowledge. It is also partly a consequence of a broader skepticism about whether introducing Sociology to students who have limited background knowledge in social, economic, and cultural history, is educationally justified. It can lead, as is evidenced from textbooks and examination scripts, to a superficiality in what students write, not through their lack of intellectual capacity, but lack of time to test out abstract sociological ideas on their experiences and on examples of empirical studies more generally.

Notoriously, such attacks also relate to disputes that occur in the school curriculum, understood as a locus of disputes between different world conceptions. Thinking about the contemporary scenario, what are the curriculum configurations and disputes that you observe in England today?

Michael Young: Two kinds of comment are worth making in response to this question. The first is that many of the most important disputes are specific to the different subjects and therefore require forms of inter-disciplinary enquiry that is still rare. It also means that, as a sociologist, while I have some limited knowledge of individual subjects, I do not have the necessary knowledge of detailed subject-specific content to make decisions.

The pressures that teachers face arise from the extent to which government interprets standards and quality in terms of increasing the stipulating of specific content. The result is the inevitable constraints of the school timetable, and an emphasis on memorization and the treating of knowledge in terms of 'bits of information' to be 'reproduced' in examinations.

Two other not unrelated trends are worth mentioning: the drift towards genericism and the greater emphasis on testing, which leads to a narrowing of the curriculum, especially for those who find learning difficult. The drift to genericism is a response to the increase in new knowledge and a narrowing of subject content that is the result of international testing regimes, such as the OECD's 
PISA assessment, which has to be applicable to an increasingly diverse range of countries. Individual sciences are replaced by scientific literacy, math, by numeracy, and literature, by literacy. The emphasis on testing impacts particularly on the primary school phase of education, as schools tend to focus on math, science, and English, and have no time to focus on the humanities and arts.

A final point worth mentioning, which is an unintended consequence of the 'knowledge turn' in curricula, relates to an earlier point about how accessing school knowledge involving a rupture with the everyday experience of students. This reflects an exaggerated response to the learner-centred policies of the previous decade. Its stress on more knowledge content can play down the extent that acquiring knowledge involves the active engagement of students.

\section{What are the main challenges of Sociology of the Curriculum today in terms of the research agenda?}

Michael Young: It is important to begin an answer to this question by stressing the relatively marginal role of 'the Sociology of the Curriculum.'

Sociology, at least outside the USA, has a long and continuing concern with educational justice. This was expressed in the 1960's and 1970's by its dominant focus on social class. However, this has broadened significantly to include gender, race, and disability, and, more recently, sexuality studies. It is not that these specialized foci are unconcerned with the curriculum; it is that they focus on specific forms of critique and identification of neglect and discrimination in their subject. Another challenge facing Curriculum Sociology is that many students find it difficult, over abstract, and over jargonised. This is partly because the word knowledge itself is so taken for granted and has very different meanings depending on the context-knowledge of the name of a cousin or nearby street and knowledge of Einstein's relativity equation! The Sociology of the Curriculum will always seem like a threat to the identity of some, but an exciting challenge to others. Not surprisingly, this poses difficulties they prefer to avoid.

\section{Thank you very much}

\section{References}

FORQUIN, J. C. Escola e cultura: as bases sociais e epistemológicas do conhecimento escolar. Porto Alegre: Artes Médicas, 1993.

MOREIRA, A. F. B.; SILVA, T. T. Sociologia e teoria crítica do currículo: uma introdução. In: MOREIRA, A. F. B.; SILVA, T. T. (orgs.). Currículo, cultura e sociedade. São Paulo: Cortez, 2002. p. 7-37.

SILVA, T. T. O que produz e o que reproduz em educação. Ensaios de Sociologia da Educação. Porto Alegre: Artes Médicas, 1992.

YOUNG, M. A propósito de uma sociologia crítica de educação. Revista Brasileira de Estudos Pedagógica, Brasília, v. 67, n. 157, p. 532-537, 1986. 
YOUNG, M. Currículo e democracia: lições de uma crítica à "nova sociologia da educação". Educação \& Realidade, Porto Alegre, v. 14, n. 1, p. 29-40, 1989.

YOUNG, M. (org.). Knowledge and control: new directions for the sociology of education. London: Collier Macmillan, 1971.

YOUNG, M. O futuro da educação em uma sociedade do conhecimento: o argumento radical em defesa de um currículo centrado em disciplinas. Revista Brasileira de Educação, Rio de Janeiro, v. 16, n. 48, 2011. https://doi.org/10.1590/S1413-24782011000300005

YOUNG, M. Para que servem as escolas? Educação \& Sociedade, Campinas, v. 28, n. 101, 2007. https://doi. org/10.1590/S0101-73302007000400002

\section{About the Authors}

Marcelo Pinheiro Cigales has a teaching degree in Social Sciences by Universidade Federal de Pelotas (UFPEL), PhD in Political Sociology by Universidade Federal de Santa Catarina (RFSC), assistant professor in the Sociology Department of Universidade de Brasília (UnB), coordinator of the Sociology Teaching Laboratory Lélia Gonzalez, and registered in $\mathrm{CNPq}$ (Sol/UnB). The author researches Sociology Teaching, and Sociology of Education.

Amurabi Pereira de Oliveira has a teaching degree and a master's degree in Social Sciences by Universidade Federal de Campina Grande (UFCG), a PhD in Sociology by Universidade Federal de Pernambuco (UFPE), and a postdoctoral stage in Universidat Autònoma de Barcelona. He is a professor in Universidade Federal de Santa Catarina (UFSC), and a researcher of CNPq. The author works, primarily, in the fields of Anthropology and Sociology of Education, Social Sciences Teaching, and Social Sciences History.

Diego Greinert De Oliveira has a teaching degree, a bachelor, and a master's degree in Social Sciences by Universidade Estadual de Londrina (UEL). He is a doctoral student of Sociology in Universidade Federal de Santa Catarina (UFSC), with a grant from Capes. Currently, the author researches the building processes of educational and curricular policies, as well as Sociology Teaching.

Received: 10 mar. 2020

Approved: 29 apr. 2020 